\title{
WEB-BASED EVENT SEMINAR REGISTRATION INFORMATION SYSTEM APPLICATION
}

\author{
${ }^{* 1}$ Rizky Febryan, ${ }^{2}$ Rogape Iansen Euclerr, ${ }^{3}$ Yulia Wardaningsih, ${ }^{4}$ Fajar Masya \\ 1,2,3,4 Program Studi Sistem Informasi \\ Universitas Mercu Buana Jakarta \\ www.mercubuana.ac.id \\ 1rizkyfebryan21@gmail.com, 2euclerr160@gmail.com,33yulia.wn13@gmail.com, \\ 4fajar.masya@mercubuana.ac.id \\ $\left.{ }^{*}\right)$ Corresponding Author
}

\begin{abstract}
Abstrak
Informasi daftar event seminar dan pendaftaran seminar yang masih dilakukan secara manual, mengakibatkan akses informasi yang disampaikan kepada para peserta seminar terbatas, selain itu proses pengolahan data yang dilakukan oleh panitia menjadi kurang efektif dan efisien. Untuk menyelesaikan permasalahan tersebut, diperlukan sebuah sistem informasi yang terkomputerisasi secara online yang dapat memberikan informasi terkait pendaftaran peserta seminar, pengelolaan data dan pelaksanaan acara seminar. Dengan diterapkannya sistem ini, diharapkan dapat mempermudah akses informasi mengenai jadwal event seminar dan mengurangi resiko kesalahan pencatatan dalam pendaftaran peserta seminar. Sistem ini juga diharapkan dapat lebih mempercepat proses pembuatan laporan yang pada akhirnya dapat membantu kinerja panitia seminar. Metode penelitian yang digunakan adalah metode survei yang melibatkan beberapa orang tertentu khususnya mahasiswa. Sedangkan untuk metode pengembangan sistem (SDLC) dilakukan dengan menggunakan metode waterfall.
\end{abstract}

Kata kunci: Pendaftaran Seminar, Sistem Informasi, Aplikasi Berbasis Web

\begin{abstract}
Information on the list of seminar events and seminar registration which is still done manually results in limited information access being given to the seminar participants, besides the data processing process carried out by the committee becomes less effective and efficient. To solve these problems, an online computerized information system is needed that can provide information related to seminar participant registration, data management, and seminar events. With the implementation of this system, it is expected to facilitate access to information about the seminar event schedule and reduce the risk of recording errors in seminar participant registration. This system is also expected to further accelerate the process of making reports which in turn can help the performance of the seminar committee. The research method used is a survey method involving certain people, especially students. Whereas the system development method (SDLC) is carried out using the waterfall method.
\end{abstract}

Keywords: Registration Seminar, Information Systems, Web Based Applications

\section{INTRODUCTION}

The system comes from Latin (Systema) and Greek (Sustema), which is a unit consisting of components or elements that are linked together to facilitate the flow of information, material, or energy. This term is often used to describe a set of entities that interact. According to (Mulyadi, 2016) The system is a group of elements that are closely related to others, which function together to achieve certain goals. A system has characteristics that are inseparable from one characteristic to another.

The word seminar comes from the Latin word "seminarium" which means "land where to plant seeds" (Ibeng, 2020). The seminar is a deliberate meeting held to be general learning on a particular topic through problem-solving that is carried out with a question and answer interactions between participants and the process is led by a moderator. These seminars are sometimes held by academics from institutions or 
professional and commercial organizations (Saranailmu, 2019).

In seminars, discussions usually originate in papers or working papers that have been prepared and prepared in advance by the speakers, and the theme of the discussion must be following the request of the organizing committee (Utama, 2017). he seminar departs from the worksheets which are a discussion of theories about the main problem that can also begin with a general view by people who are considered to be competent to lay the lines of thought further (Barlian, 2014). Participating in people who are experts in their fields. The seminar on marketing a product, certainly attended by experts in marketing. Educational seminars are naturally attended by experts in education (Damanik, 2018). The seminar involved two parties, namely presenters and participants. Both parties must be able to complement each other and develop beneficial interactive relationships in terms of the aims and objectives of the seminar. Some of the requirements for running a seminar with the seminar room, participants, and moderators.

A seminar event can be used as an example in the use of technology, a seminar event is an activity planned to provide experience to seminar participants in conducting a thorough study of a particular topic with problem-solving. To attract seminar participants' interest, an advertisement/information about the list of activities is needed that can provide ease in registration and the latest schedule information regarding the list of seminar events.

To make it easier for participants to find information on seminar event registration, an interesting and applicative computerized information system is needed online. This is a motivation for writers to make a seminar event registration information system application that can help the performance of the seminar committee in accelerating the process of recording data and making reports. The research method used was a survey method. In surveys, information is collected from respondents using a questionnaire. Generally, survey research is limited to studies whose data are collected from a sample of the population to represent the entire population (Adiyanta, 2019). The system development model in this study is the waterfall model (Aediyansyah, 2018). The purpose of this research is to facilitate seminar participants in finding various types of seminar events, online registration processes, good data management by the system, making data reports more efficient and valid, and how to pay.

\section{RESEARCH METHODS}

\section{Type of Research}

This type of research used by using survey methods in the form of data collection using a questionnaire and looking for a literature study.

\section{Research Location}

The research location is where the research is conducted to obtain data. The study was conducted by the writer randomly in several places around the campus and offices with the target subject being students. Problems that will be faced include the limitations of cost, manpower, time, for what the research is done, and who the researchers are carrying out.

\section{Data Collection Techniques}

The following data collection techniques are used by the author in developing information systems for seminar event list:

a. Questionnaire

Collecting data by giving multiple-choice questions to respondents to obtain data on perceptions from respondents.

b. Literature Review

Collecting data by examining various kinds of documents that have to do with problems that must be solved for analysis material. Research carried out by examining and comparing literature sources to obtain theoretical data.

\section{System Development Model}

The stages carried out for the development of this application with the waterfall method are divided into five stages, namely:

a. Needs Analysis/Requirements Analysis

At this stage is the process of gathering needs for the use of the system both functional and nonfunctional requirements for this application.

b. Design

The stages of designing a system that includes application design and UML design.

c. Coding (Implementation)

At this stage is the process of writing program codes with WordPress CMS using HTML and PHP languages and MySQL as DBMS.

d. Testing

Stages that focus on ensuring a smooth application. Testing in this study uses black-box testing.

e. Maintenance (Support)

This stage is the stage of system maintenance that has been made. Maintenance is carried out by rearranging the database and backing up data. 


\section{RESEARCH RESULTS AND DISCUSSION}

\section{A. Requirements Analysis}

\section{Functional Requirements Analysis}

In making the application system registration information web-based seminar event has three levels of users, namely members, seminar owners, and admins. The following are details of 3 user levels, namely:

a. Member

1) See the seminar list available on the website application

2) Register an account on the website application as a seminar registrar using an email account (recommended to use an active email account)

3) Manage profile/update profile

4) Register the seminar that has been made by the seminar owner

5) View the seminar history that has been registered

6) Make changes to payment photo uploads

b. Seminar Owner (Pemilik Seminar)

1) Register an account on the website application as the seminar owner using an email account (it is recommended to use an active email account)

2) Manage profile/update profile

3) Create a new seminar

4) Conduct seminar management that has been created (edit and delete)

5) See the seminar list that has been created

6) See the list of seminar registrants who have registered at the seminar owned by the seminar owner

7) End (selesai) the seminar that has finished/complete the seminar that has been confirmed by the seminar owner so that the Admin can transfer the money from the seminar that has been allocated to the seminar owner

8) Export seminar data so that the data becomes more organized for the analysis process

9) See the results of seminar transfer evidence that has been accumulated by the admin

c. Admin

1) Conduct user management (member and seminar owner)

2) Conduct seminar registration management (validation of registration) so that seminar participants who have been confirmed can be seen by the seminar owner

3) See the list of seminar applicants who have been verified by the admin
4) Conduct seminar management that has been completed (selesai) by the seminar owner so that the accumulated results (profit sharing) of seminar costs owned by the seminar owner will then be transferred to the seminar owner

\section{Nonfunctional Requirements Analysis}

Non-functional requirements analysis describes the system requirements specification in the form of software and hardware requirements as material to analyze the needs and shortcomings that must be met to build this system.

a. Software Requirements $\mathrm{k}$

Minimum Operating System Windows 7; Web Browser (Google Chrome/Mozilla Firefox); Apache Webserver; PHP script language, MySQL Database

b. Hardware Requirements

CPU: 1.2 GHz; Memory (RAM): 512MB; GPU

RAM: 1GB; HDD: 50GB

\section{Business Process Analysis}

In making the Web-Based Event Registration Information System Application, a business process analysis is needed to make it easier for the user system to carry out all activities and achieve goals. The following is an analysis of the proposed business process :

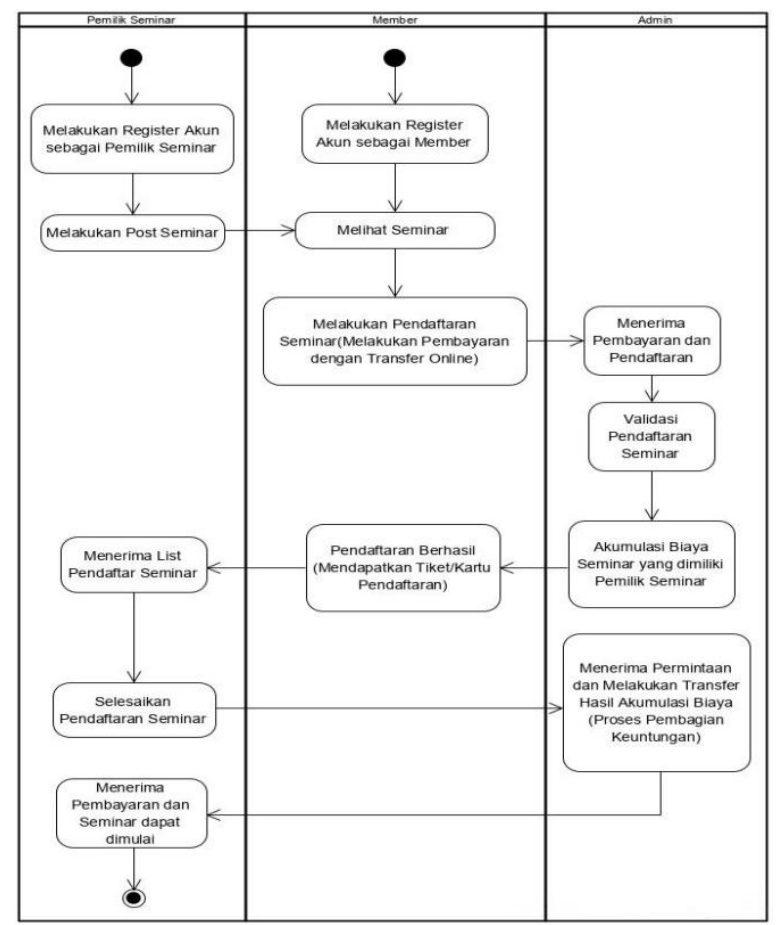

Figure 1 Business Process Analysis

In Figure 1 the analysis phase of this business process, the Seminar Owner will register an account as the seminar owner then can make/post new seminars.. Furthermore, in the 
Member section will also register an account as a member (registrant seminar) and then can see the results of the seminar that has been made by the Seminar Owner so that Members can register for the seminar. After the Member has successfully registered, the Admin will receive the results of the registration from the Member so that the Admin can validate the registration and accumulate the total seminar costs held by the Seminar Owner. The results of the validation conducted by the Admin will be received by the Member and the Member will get a notification of successful seminar registration and a ticket/registration card. Then the Seminar Owner will receive a list of seminar attendees and can see the results of the accumulated costs that will be the benefit of the Seminar Owner. After several Members have registered at the seminar that was made by the Seminar Owner and have passed the date on the seminar registration, the Seminar Owner can conduct an "end seminar" (selesai) so that the Admin can transfer the total seminar cost. Admin receives the transfer request for the results of accumulated costs (profit sharing between the Seminar Owner and Admin) and then transfers the fee to the Seminar Owner. At the end of this business process, Seminar Owners will receive the results of transfer fees from the Admin so that the seminar can begin.

\section{B. Design \\ 1. Application Design}

\section{a. Use Case Diagram}

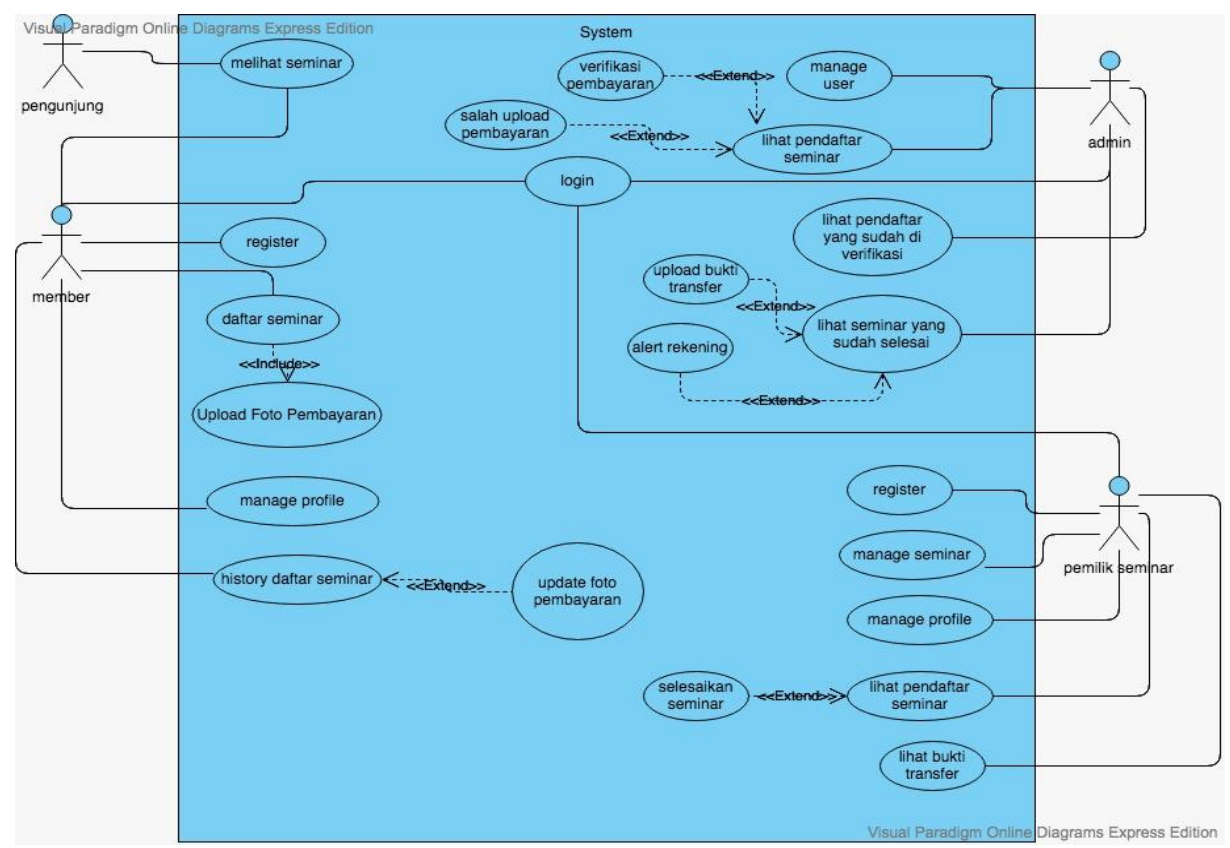

Figure 2. Use Case Application Diagram

Figure 2 explains that Visitors can view the seminar. Members can also view seminars, members must register to be able to log in, then login to register for seminars, upload payment photos, manage profiles, view seminar list history, and update payment photos. The Seminar Owner must also register to be able to log in, then login as well to be able to see proof of transfer, see the seminar registrant, end (selesai) the seminar, manage the seminar, and manage the profile. Whereas an Admin must log in to be able to manage users, view seminar registrants, verify payments, upload payment errors, view verified registrants, view completed/end seminars, upload proof of transfer, and account alerts.

\section{b. Activity Diagram}

In this activity diagram, the focus is more on the seminar registration section conducted by Members and the registration relationship between Members and Admin. 


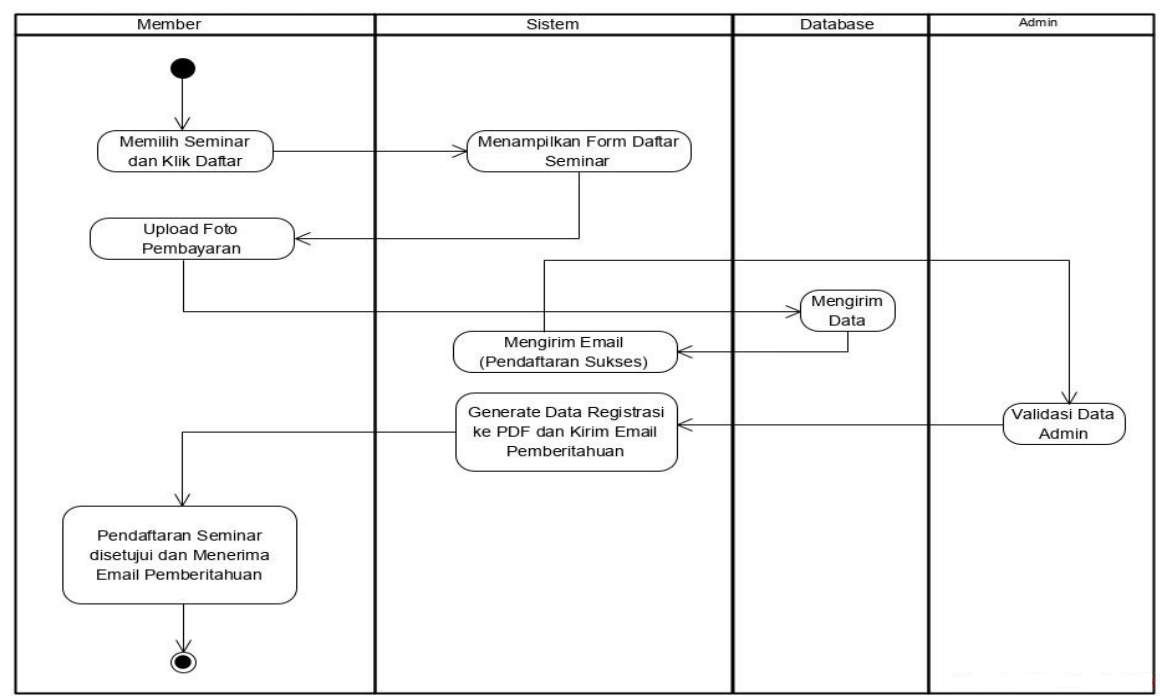

Figure 3. Activity Diagram Registration Seminar

Explanation of Figure 3 that when wanting to register the Member will select the seminar to be registered then click on the seminar list and the system will display a form containing the registrant data. At this stage, it is assumed that the Member has seen the registration requirements as well as the Admin bank account information to transfer the registration fee. On the registration form, the system will automatically input the registrant's name and email registrant so that the registrant (Member) only needs to upload a payment photo and the seminar registration process is complete. After registration is complete, members will get an email notification "successful registration" and wait for the validation notification from the Admin. If the validation has been received by the Admin, the Member will receive email notification of successful verification and get a ticket/registration card.

\section{Interface Display}

a. Form Create Seminar Display

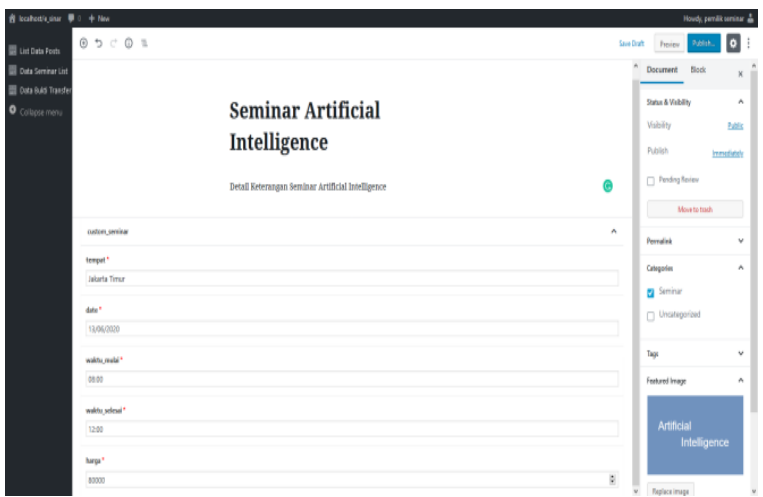

Figure 4. Form Create Seminar Display
Figure 4 is a display form of making a new seminar that can be done by the Seminar Owner. In this picture the Seminar Owner fills in the seminar title form, details of the seminar's information, place, date, time, cost, uploads the seminar display photo, and selects the seminar category for the seminar choice.

b. Page Seminar List Display

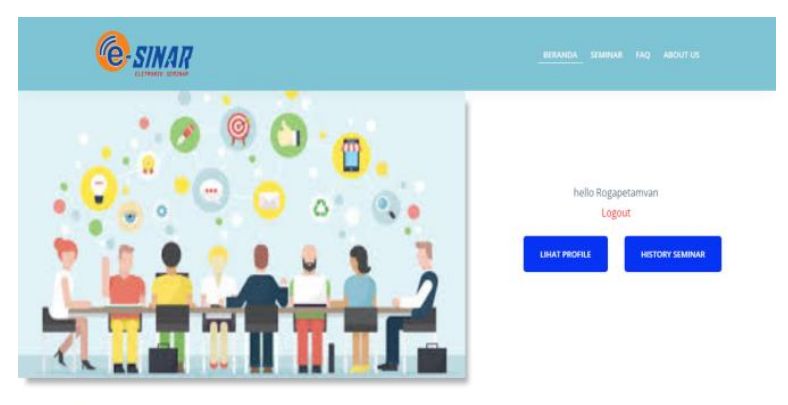

list seminar
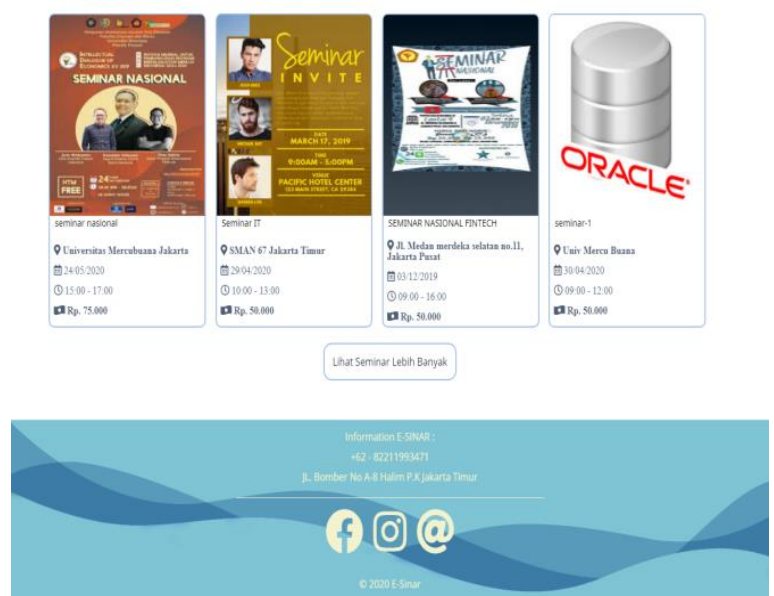

Figure 5. Page Seminar List Display 
Figure 5 is the initial page display of the application after the Member has logged in which displays all seminar lists that have been created by all Seminar Owners.

c. Form Registration Seminar Display
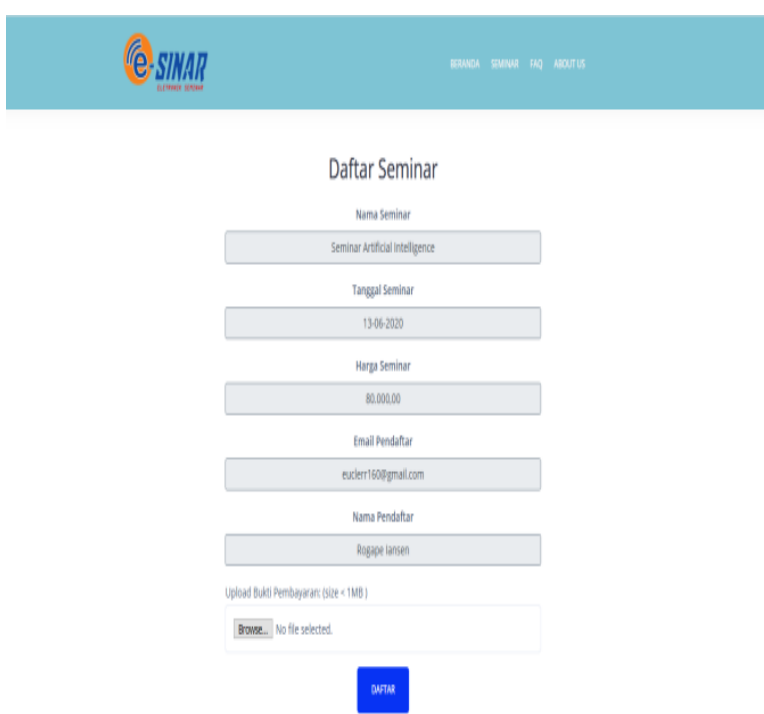

Figure 6. Form Registration Seminar Display

Figure 6 shows the seminar registration form. In this form Members only need to upload payment photos with a maximum file size of $1 \mathrm{MB}$.

\section{d. Seminar Registrant Display (Seminar} Validation)

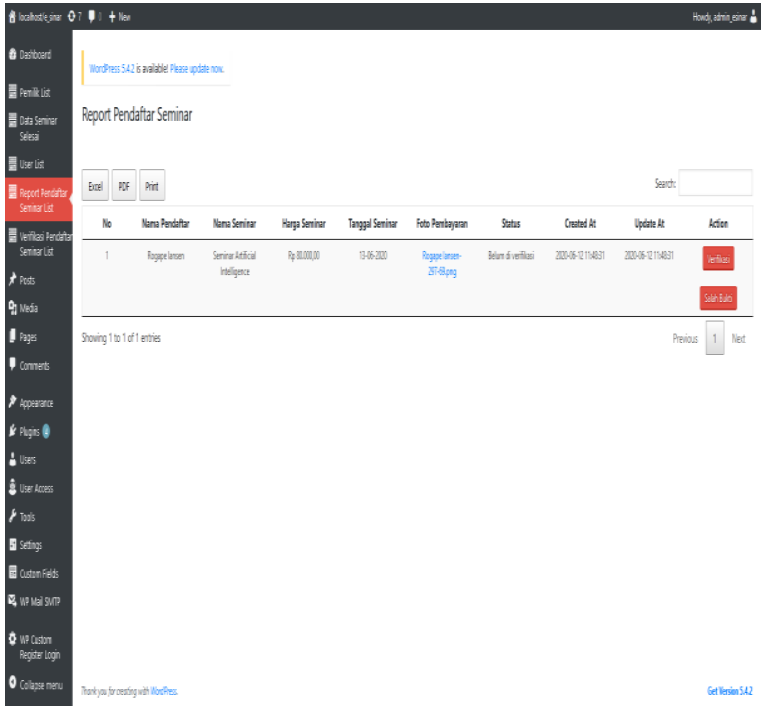

Figure 7 Seminar Registrant Display

Figure 7 is a list of seminar applicants for all available seminars. At this stage, the Admin validates the matching proof of payment upload.

\section{e. Seminar Registration History Display}

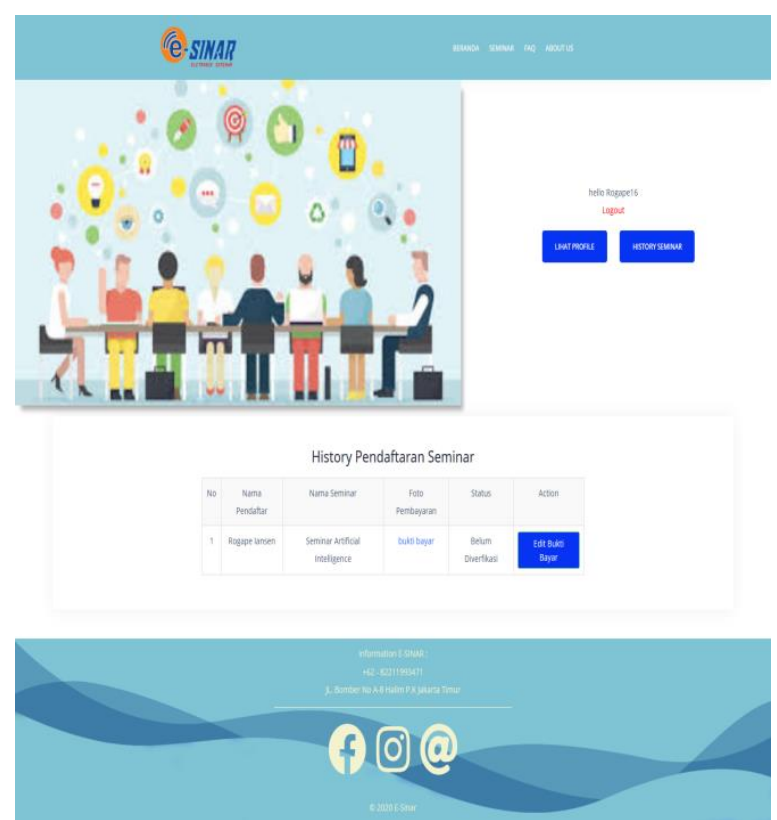

Figure 8. Seminar Registration History Display 1

Figure 8 is a display of the seminar history that has been registered by the Member. Displays seminar status to find out whether the registration has been verified or not.

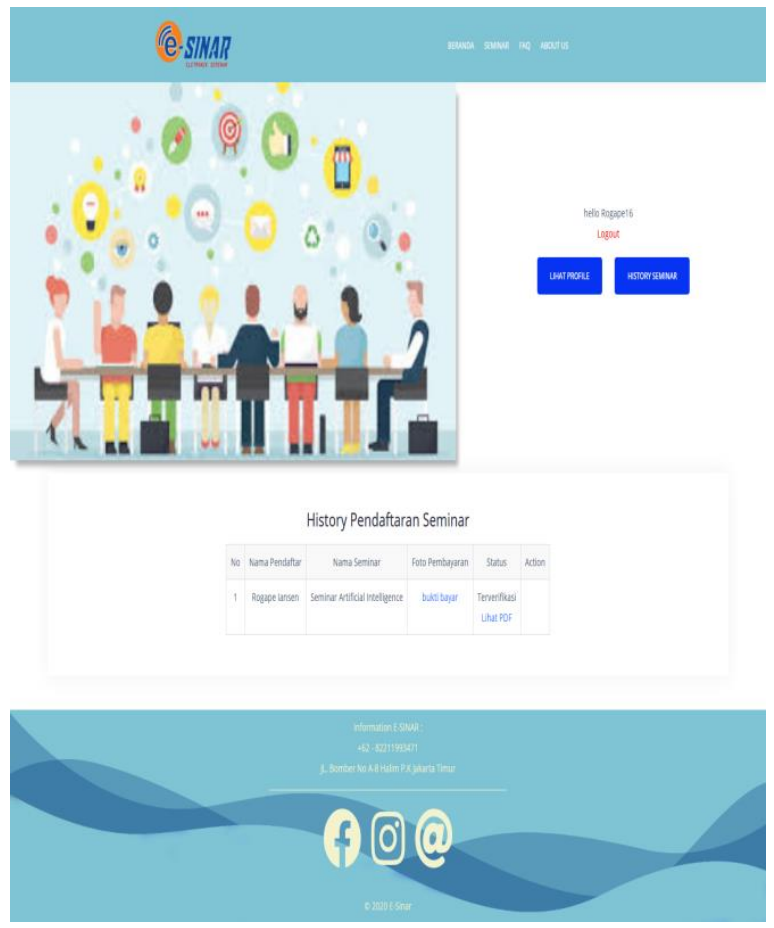

Figure 9. Seminar Registration History Display 2

Figure 9 is a display of seminar history that has verified the status of the seminar by the Admin. 


\section{f. Seminar List Data Display (end seminar)}

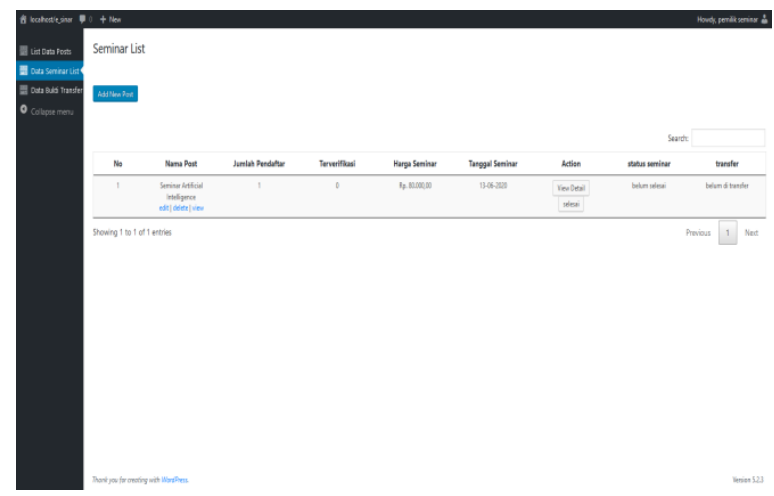

Figure 10. Seminar List Data Display

Figure 10 shows the seminar list data display. The Seminar Owner can view the financial details of the seminar and the seminar registrant if the seminar registration time has ended, the Seminar Owner can "finish" so that the accumulated costs by the Admin can be passed on to the Seminar Owner.

\section{g. Seminar Data Completed/Ended Display}

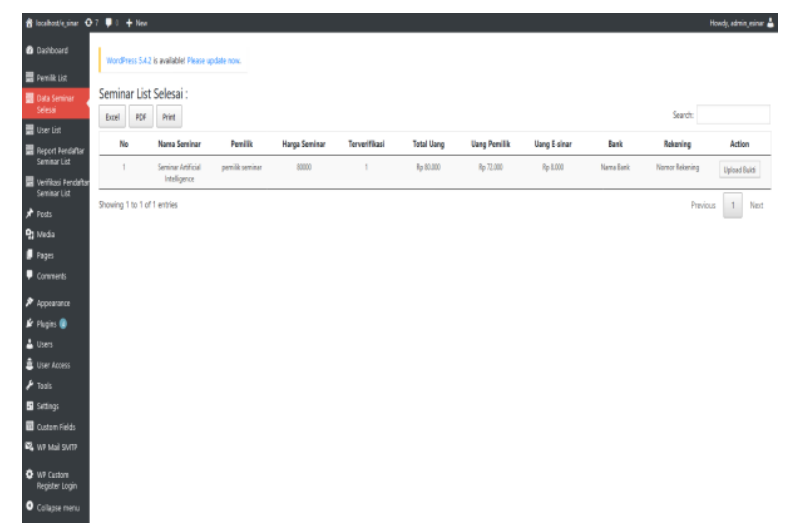

Figure 11. Seminar Data Completed/Ended Display

Figure 11 is a list of completed/ended seminars. Admin will transfer seminar fees (accumulated fees) as stated in the "owner's money" section and upload proof of payment.

h. Data Transfer Receipt Display

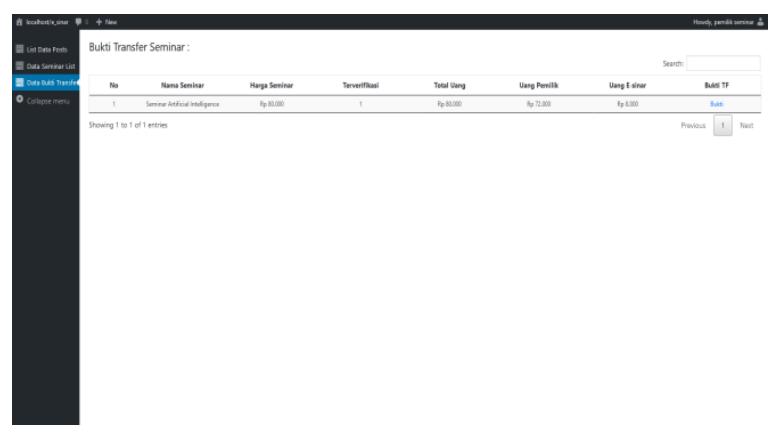

Figure 12. Data Transfer Receipt Display

Figure 12 is a display of proof of transfer data owned by the Seminar Owner. On this page, the Seminar Owner can see proof of the transfer that has been done by the Admin.

\section{Application Coding}

At the coding stage of the Web-Based Event Registration Information System Application, the writer cannot show it because the source code of the program is very large. For this reason, the writer will mention the programming language used to build this application. The programming languages used are HTML, PHP, CSS, and using Wordpress's CMS (Content Management System) type.

\section{Application Testing}

Testing on making Web-Based Event Registration Information System Application using the black-box testing method can be seen in table 1 , table 2 , and table 3 below. 


\begin{tabular}{cllll}
\hline No & $\begin{array}{l}\text { System } \\
\text { Components }\end{array}$ & Test Item & Expected Results & Test Result \\
\hline 3 & $\begin{array}{l}\text { Seminar } \\
\text { detail page }\end{array}$ & $\begin{array}{l}\text { Access the details of the } \\
\text { selected seminar }\end{array}$ & $\begin{array}{l}\text { Displays the details page of the selected } \\
\text { seminar }\end{array}$ & Successful \\
\hline 4 & $\begin{array}{l}\text { Register } \\
\text { seminar }\end{array}$ & $\begin{array}{l}\text { Register (Daftar) } \\
\text { seminar button }\end{array}$ & Access the seminar list page & Successful \\
\hline & $\begin{array}{l}\text { Seminar list form } \\
\text { validation }\end{array}$ & $\begin{array}{l}\text { Displays error validation if the uploaded } \\
\text { photo is more than 1 MB }\end{array}$ & Successful \\
\hline & Button Register & $\begin{array}{l}\text { Successfully register for the seminar if the } \\
\text { form is correct and send an email } \\
\text { notification that registration }\end{array}$ & Successful \\
\hline 5 & Logout & Logout & Logout from account successfully & Successful \\
\hline
\end{tabular}

Table 1 is a testing table of member actors. This stage of testing involves registering an account (as a seminar registrar), logging in an account, accessing the seminar details page, conducting a seminar list, and account logout.

Table 2. Seminar Owner Testing Table

\begin{tabular}{|c|c|c|c|c|}
\hline No & $\begin{array}{l}\text { System } \\
\text { Components }\end{array}$ & Test Item & Expected Results & Test Result \\
\hline \multirow[t]{3}{*}{1} & Register & $\begin{array}{l}\text { Access the form } \\
\text { register }\end{array}$ & $\begin{array}{l}\text { Displays a pop up (register form) after } \\
\text { clicking the register button }\end{array}$ & Successful \\
\hline & & $\begin{array}{l}\text { Register form } \\
\text { validation }\end{array}$ & $\begin{array}{l}\text { Displays form validation if there are errors } \\
\text { in filling out the form }\end{array}$ & Successful \\
\hline & & $\begin{array}{l}\text { Register an } \\
\text { account }\end{array}$ & $\begin{array}{l}\text { Successfully registered as the owner of the } \\
\text { seminar after completing the form } \\
\text { correctly }\end{array}$ & Successful \\
\hline \multirow[t]{3}{*}{2} & Login & $\begin{array}{l}\text { Access the login } \\
\text { form }\end{array}$ & $\begin{array}{l}\text { Displays a pop up (login form) after } \\
\text { clicking the login button }\end{array}$ & Successful \\
\hline & & $\begin{array}{l}\text { Login form } \\
\text { validation }\end{array}$ & $\begin{array}{l}\text { Displays form validation if there are errors } \\
\text { in filling out the form }\end{array}$ & Successful \\
\hline & & Account login & Successfully logged in as seminar owner & Successful \\
\hline 3 & $\begin{array}{l}\text { Enter the } \\
\text { dashboard }\end{array}$ & $\begin{array}{l}\text { Owner's } \\
\text { dashboard } \\
\text { button }\end{array}$ & Displays the owner's dashboard page & Successful \\
\hline \multirow[t]{2}{*}{4} & Create a seminar & $\begin{array}{l}\text { Button add a } \\
\text { new post }\end{array}$ & Displays the seminar creation page & Successful \\
\hline & & Publish button & Publish seminars that have been made & Successful \\
\hline 5 & $\begin{array}{l}\text { View seminar } \\
\text { details }\end{array}$ & $\begin{array}{l}\text { Detail view } \\
\text { button on the } \\
\text { seminar list data } \\
\text { page }\end{array}$ & $\begin{array}{l}\text { Display data in detail (financial \& } \\
\text { registrant list) at selected seminars }\end{array}$ & Successful \\
\hline 6 & $\begin{array}{l}\text { Complete/ended } \\
\text { the seminar }\end{array}$ & $\begin{array}{l}\text { Button finishes } \\
\text { (selesai) on the } \\
\text { seminar list data } \\
\text { page }\end{array}$ & $\begin{array}{l}\text { Complete (ended) the seminar \& change } \\
\text { the status of the seminar to be completed } \\
\text { at the selected seminar }\end{array}$ & Successful \\
\hline \multirow[t]{2}{*}{7} & $\begin{array}{l}\text { Proof of data } \\
\text { transfer menu }\end{array}$ & $\begin{array}{l}\text { Access the proof } \\
\text { of data transfer } \\
\text { page }\end{array}$ & Displays proof of transfer data page & Successful \\
\hline & & $\begin{array}{l}\text { Button proof } \\
\text { (bukti) }\end{array}$ & $\begin{array}{l}\text { See photo of proof of transfer from the E- } \\
\text { Sinar }\end{array}$ & Successful \\
\hline 8 & Logout & Logout & Logout from account successfully & Successful \\
\hline
\end{tabular}

Table 2 is a testing table of the seminar owner actors. This stage of testing consists of registering an account (as a seminar owner), logging in an account, accessing the dashboard of the seminar owner, making seminars, viewing details of the seminar that was created, executing the seminar completion/ended seminar, accessing the proof of transfer menu, and logging out of the account. 
Table 3. Admin Testing Table

\begin{tabular}{|c|c|c|c|c|}
\hline No & $\begin{array}{l}\text { System } \\
\text { Components }\end{array}$ & Test Item & Expected Results & Test Result \\
\hline \multirow[t]{2}{*}{1} & $\operatorname{login}$ & $\begin{array}{l}\text { Access the login page on the } \\
\text { link } \\
\text { http://localhost/e_sinar/wp- } \\
\text { admin }\end{array}$ & Displays the login page & Successful \\
\hline & & Login button & $\begin{array}{l}\text { Enter the admin dashboard page of the form } \\
\text { is filled incorrectly }\end{array}$ & Successful \\
\hline 2 & $\begin{array}{l}\text { List seminar } \\
\text { owner page }\end{array}$ & $\begin{array}{l}\text { Access the menu page of the } \\
\text { list seminar owner }\end{array}$ & Displays the list seminar owner page & Successful \\
\hline \multirow[t]{4}{*}{3} & $\begin{array}{l}\text { Seminar } \\
\text { registration report } \\
\text { page }\end{array}$ & $\begin{array}{l}\text { Access the seminar list } \\
\text { registrant report page }\end{array}$ & $\begin{array}{l}\text { Displays the seminar list registrant report } \\
\text { page }\end{array}$ & Successful \\
\hline & & Payment photo & Showing photos of payment from members & Successful \\
\hline & & $\begin{array}{l}\text { Verification (verifikasi) } \\
\text { button }\end{array}$ & $\begin{array}{l}\text { Verifying member registration at the } \\
\text { seminar, changing the registration status and } \\
\text { sending a verified email to the member email }\end{array}$ & Successful \\
\hline & & $\begin{array}{l}\text { Incorrect proof (salah bukti) } \\
\text { button }\end{array}$ & $\begin{array}{l}\text { Change the registration status to upload } \\
\text { incorrect evidence and send a member alert } \\
\text { containing error uploading evidence }\end{array}$ & Successful \\
\hline \multirow[t]{6}{*}{4} & $\begin{array}{l}\text { Seminar data page } \\
\text { complete/ended }\end{array}$ & $\begin{array}{l}\text { Accessing completed/ended } \\
\text { seminar data page }\end{array}$ & $\begin{array}{l}\text { Displaying the seminar data page that has } \\
\text { completed/ended }\end{array}$ & Successful \\
\hline & & $\begin{array}{l}\text { Button upload proof (upload } \\
\text { bukti) }\end{array}$ & Display the proof upload form page & Successful \\
\hline & & Validate upload form & $\begin{array}{l}\text { Displays an error message if the uploaded } \\
\text { photo is more than } 1 \mathrm{MB}\end{array}$ & Successful \\
\hline & & $\begin{array}{l}\text { Button sends proof (kirim } \\
\text { bukti) }\end{array}$ & $\begin{array}{l}\text { Successfully upload proof of transfer and } \\
\text { changed status to completed transfer }\end{array}$ & Successful \\
\hline & & Button transfer complete & See the upload of evidence & Successful \\
\hline & & $\begin{array}{l}\text { Account alert button (alert } \\
\text { rekening) }\end{array}$ & $\begin{array}{l}\text { sending email alerts containing incomplete } \\
\text { owner account data to owner email }\end{array}$ & Successful \\
\hline 5 & logout & Logout & Logout from account successfully & Successful \\
\hline
\end{tabular}

Table 3 is a testing table from the admin actor. The stages of this test are doing an account login (admin account login), accessing the seminar owner list page, accessing the seminar registration report, accessing the completed/ended seminar page, and account logout.

\section{CONCLUSIONS AND SUGGESTIONS}

\section{Conclusions}

The seminar is needed by some people, especially students. There are several obstacles to being able to take part in the seminar, one of which is information about the seminar. In helping to solve these problems, a Web-Based Seminar Event Registration Information System Application was made. This application can be accessed at any time, making it easier for seminar participants to find various types of seminar events, online registration processes, good data management by the system, making data reports more efficient and valid, and how to pay.

\section{Suggestions}

Payment for seminar events can be done through OLP (Online Payment) so that if there is a problematic network the seminar participants can make payments by other methods.

\section{REFERENCE}

Adiyanta, F. C. . (2019). Hukum dan Studi Penelitian Empiris: Penggunaan Metode Survey sebagai Instrumen Penelitian Hukum Empiris. Adminitrative Law \& Governance Journal., 2(4), 697-709. https://ejournal2.undip.ac.id/index.php/alj/ article/view/6604

Aediyansyah, A. (2018). PERANCANGAN SISTEM INFORMASI PENJUALAN DAUR ULANG BOTOL BEKAS (PET) BERBASIS WEB. Jurnal Riset Informatika, 1(1), 11-16. https://doi.org/10.34288/jri.v1i1.5

Barlian, E. (2014). Seminar dan Karya Ilmiah. In Sukabina Press (1st ed.). Penerbit Sukabina Press. https://osf.io/preprints/inarxiv/jt2by

Damanik, E. (2018). DAMPAK SEMINAR DAN WORKSHOP ACCURATE TERHADAP MINAT 
BELAJAR SOFTWARE AKUNTANSI. Jurnal Teknik Informasi Dan Komputer (Tekinkom), 1(1), $\quad$ 41-46. https://doi.org/10.37600/tekinkom.v1i1.50

Ibeng, P. (2020). Pengertian Seminar. Pendidikan.Co.Id.

https://pendidikan.co.id/pengertianseminar/

Mulyadi. (2016). Sistem Akuntansi. Salemba Empat; Penerbit Salemba Empat. https://www.gramedia.com/sistemakuntansi-edisi-4.html

Saranailmu. (2019). Seminar: Pengertian, Definisi, Ciri Ciri, Susunan, Fungsi dan Pihak yang Terlibat. Weschool.Id. https://www.weschool.id/seminar-definisiciri-ciri-susunan-fungsi-dan-pihak-yangterlibat/

Utama, I. W. A. M. (2017). Hakikat Seminar Pendidikan. In ResearchGate (Vol. 1). https://www.researchgate.net/publication/ 315054343_Hakikat_Seminar 